\title{
Plant-canopy Effects on Natural Regeneration in Sites Under Restoration: Do Tree Species Matter?
}

\author{
Lohana Lopes Lameira ${ }^{1}$, Fernanda Cunha Gonçalves Ferreira ${ }^{1}$, \\ Rodrigo Antônio Esteves Filardi ${ }^{1}$, Jarbas Marçal Queiroz ${ }^{1}$, \\ Jerônimo Boelsums Barreto Sansevero ${ }^{1}$ \\ ${ }^{1}$ Universidade Federal Rural do Rio de Janeiro - UFRRJ, Serópédica/RJ, Brasil
}

\begin{abstract}
How does species choice influence ecological restoration outcomes? In order to answer this question, the goal of this study was to assess the community structure and species richness of natural regeneration beneath the canopy of four native species from the Atlantic Forest (Guarea guidonia (L.) Sleumer; Inga edulis Mart; Nectandra membranacea (SW) Griseb; and, Piptadenia gonoacantha (Mart.) J.F. Macbr). The research was carried out in plantations of native tree species at the Guapiaçu Ecological Reserve, in Rio de Janeiro State, Brazil. Our results pointed that abundance, basal area and species richness were significantly higher beneath Inga compared to Nectandra and Guarea. Whereas the lowest values observed in Guarea may suggest its negative effects under natural regeneration. Therefore, we highlighted that the positive or negative biological effects of tree species, instead of their simple response (mortality and initial growth), must be considered in ecological restoration projects.
\end{abstract}

Keywords: Atlantic Forest, ecological filter, plant-plant interaction, facilitation, Inga edulis. 


\section{INTRODUCTION}

Natural regeneration has been regarded as the main indicator of success in the restoration of degraded lands (Holl \& Aide, 2011; Sansevero \& Garbin, 2015). Seed dispersal, seedling establishment, and the persistence of seedlings are fundamental for biodiversity maintenance and the recovery of ecological processes in sites under restoration (Carnevale \& Montagnini 2002; Sansevero et al., 2011; Suganuma et al., 2014). Thus, the absence of natural regeneration can compromise biodiversity maintenance in the long term (Souza \& Batista, 2004). Of the factors that influence natural regeneration in tropical forests, three should be highlighted: distance from forest remnants (McConkey et al., 2012), abiotic conditions (e.g. soil features; Mendes et al., 2018), and competitive exclusion by invasive grasses (Scervino \& Torezan, 2015). Therefore, in sites with low rates of natural recovery, active restoration techniques (such as tree planting) have been proposed in order to catalyze ecological succession (Holl \& Aide, 2011).

Tree planting is the most common active restoration technique in tropical forests (Lamb et al., 2005; Rodrigues et al., 2011). Considering the specific managerial attributes that affect the restoration success of tree plantations, the following question has been raised: How does species choice influence restoration outcome? Previous studies have demonstrated the role of the structure and species composition of the overstory on natural regeneration (Thijs et al., 2014). Consequently, tree species differ in their ability to modify abiotic conditions and promote positive (e.g., facilitative) or negative (e.g., competitive) biotic interactions at the community scale (Mesquita et al., 2001; Garbin et al., 2013; Pistón et al., 2018). Hence, better understanding the effects of different tree species on natural regeneration and ecological processes is a key tool for achieving restoration success. Communities or plants with different functional traits can be used in restoration projects to assess species effects on ecological processes (Cadotte et al., 2011; Laughlin, 2014; Ostertag et al., 2015).

Plant functional traits can be defined as those traits important for determining a species' response to the environment and/or important for ecosystem functioning (Díaz \& Cabido 1997). In other words, plant functional traits can be classified as response (e.g., performance) or effect (e.g., nutrient cycling or facilitation) traits (Lavorel \& Garnier 2002; McGill et al., 2006). Historically, ecological restoration studies have focused on response traits in the face of environmental conditions and/or perturbations (e.g., fire, landslides, mining; Elliott et al., 2003; Ostertag et al., 2015). This is clearly related to the need to ensure survival and increase seedling growth, in order to enhance restoration success (Grossnickle, 2012). However, even projects considered initially successful have not achieved the reestablishment of ecological processes, probably because of limited timeframes and the decoupling of response and effect traits (e.g. Díaz \& Cabido, 1997). Several studies have demonstrated the effects of species identity on ecological conditions and processes, such as soil properties (Garbin et al., 2006), light regimes (Gandolfi et al., 2007), seed rain (Clark et al., 2004), and natural regeneration (Souza et al., 2014) beneath tree canopies. Thus, the search for patterns in the effects of species identity on ecosystem functioning may represent a paradigm shift in ecological restoration, since species effects will be considered an important criterion for species selection in restoration projects.

In this study, we investigate natural regeneration beneath four native Atlantic Forest tree species (Guarea guidonia (L.) Sleumer; Inga edulis Mart; Nectandra membranacea (SW) Griseb; and Piptadenia gonoacantha (Mart.) J.F. Macbr) in sites under restoration. These tree species were selected based on three functional traits: deciduousness (deciduous or evergreen), dispersal syndrome (biotic or abiotic), and nitrogen-fixing ability (presence or absence). All these functional traits can lead to changes in natural regeneration, considering their effect on light availability in the understory (Gandolfi et al., 2007), improvement in soil conditions (Siddique et al., 2008), and seed and fruit attractiveness to dispersers (Fink et al., 2009). Therefore, we hypothesized that the community structure (abundance and basal area), richness, and species composition of natural regeneration beneath the canopy would differ among the four focal tree species. We expected that zoochorous (I. edulis, G. guidonia, and N. membranacea) and nitrogen-fixing (I. edulis and $P$. gonoacantha) species would have a positive effect on natural regeneration. We believe that our study will contribute to both theoretical and practical aspects of ecological restoration, especially concerning the current opportunities and challenges facing restoration ecology in Brazil (see Scaramuzza et al., 2017; Isernhagen et al., 2017). 


\section{MATERIAL AND METHODS}

\subsection{Site description}

The study was carried out in the Guapiaçu Ecological Reserve (hereafter, GER; $22^{\circ} 25^{\prime} 10^{\prime \prime} \mathrm{S}$ and $42^{\circ} 46^{\prime} 13^{\prime \prime} \mathrm{W}$ ), Rio de Janeiro state, southeastern Brazil. The GER was designated a Conservation Unit (Reserva Particular do Patrimônio Natural - RPPN) in 1996 due to its importance for biodiversity conservation, especially that of bird species. The mean temperature is about $23{ }^{\circ} \mathrm{C}$ and the annual rainfall is around 2,500 $\mathrm{mm}$ (Azevedo, 2012). According to the Brazilian Vegetation System, the vegetation of GER is classified as ombrophilous forest (Veloso et al., 1991). The GER is 7380 ha in extent, of which around $94 \%$ is covered by old-growth remnants of the Brazilian Atlantic Forest (Lindner \& Sattler, 2012). However, in the past, some areas, mainly in the lowlands, were degraded by deforestation and the use of land to cultivate pastures and agricultural crops. This has recently motivated the implementation of restoration projects in the area (Azevedo, 2012). Our study was conducted at a 13-year-old restoration project site that covered 12 ha of areas previously used as pastures (Azevedo, 2012).

\subsection{Data collection and analysis}

We selected four native tree species: Piptadenia gonoacantha (Fabaceae), Inga edulis (Fabaceae), Guarea guidonia (Meliaceae), and Nectandra membranacea (Lauraceae). These species were selected based on differences in their functional traits (Table 1), which suggested that they would have distinct effects on natural regeneration, and because all of them had often been used in restoration projects in the Brazilian Atlantic Forest (Sansevero et al., 2011; Azevedo, 2012). We randomly selected 14 to 16 focal individuals of each tree species (Table 1) with a diameter at breast height $(\mathrm{DBH})$ of $>10 \mathrm{~cm}$, a canopy diameter of at least $2 \mathrm{~m}$, and without canopy overlap with other species. These criteria were used in order to ensure that species-specific effects on natural regeneration would be captured, and to reduce any confounding bias that could be attributed to the neighboring vegetation. Community structure, richness, and the species composition of the natural regeneration beneath each tree species were censused in $1.8 \mathrm{~m}$-radius circular plots $\left(11.3 \mathrm{~m}^{2}\right)$. All individual naturally regenerated plants, comprising woody species taller than $0.5 \mathrm{~m}$ and with a $\mathrm{DBH}$ of $<5 \mathrm{~cm}$, were measured (height and diameter), collected, and identified at the Rio de Janeiro Botanical Garden Herbarium (RB). The Angiosperm Phylogeny Group IV nomenclature was used to determine the family nomenclature (APG IV 2016).

Statistical differences between tree species (Piptadenia, Inga, Guarea, and Nectandra) were tested using either analysis of variance (ANOVA) followed by post hoc Tukey test ( $\alpha$ for all tests $=0.05$ ) or a non-parametric test (Kruskal-Wallis). These analyses were performed using the InfoStat software (Di Rienzo et al., 2011). Indicator species analysis (ISA; Dufrêne \& Legendre, 1997) was used to test for differences in the species composition of the naturally regenerated vegetation beneath each tree species. For this analysis, only occurrence values above 0.25 were considered for the statistical tests, as suggested by Dufrêne \& Legendre (1997). The ISA analysis was performed using the labdsv package in the $\mathrm{R}$ environmental (available at http://ecology.msu.montana.edu/ labdsv/R/labdsv), R v.3.2.1 (R Core Team, 2016).

\section{RESULTS}

We sampled 60 species, belonging to 45 genera and 28 families, in the natural regeneration sites beneath all focal tree species. Inga exhibited the highest

Table 1. Tree species used in the study, number of sampled individuals of each species, and their functional traits (dispersal syndrome, leaf-loss strategy, and nitrogen-fixing ability).

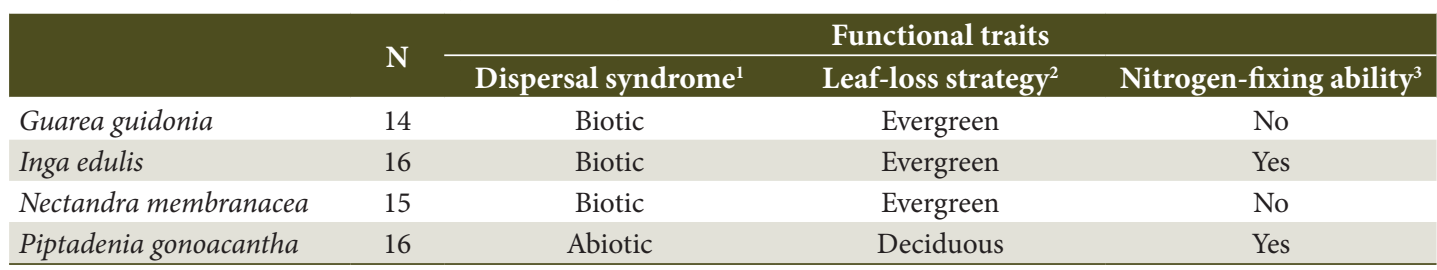

${ }^{1}$ Canosa \& Moraes (2016). ${ }^{2}$ WebAmbiente (2018). ${ }^{3}$ Canosa \& Moraes (2016). 
mean values for abundance, basal area, and species richness of seedlings, followed by Piptadenia, Guarea, and Nectandra (Figure 1). All variables exhibited statistically significant differences among the focal tree species (Figure 1). Rarefaction curves indicated that the species richness of the natural regeneration beneath Inga trees was highest, followed by that beneath Nectandra trees (Figure 2). These results also revealed that the seedling assemblages beneath Inga and Nectandra had a higher beta diversity than those beneath Piptadenia and Guarea. The ISA yielded one
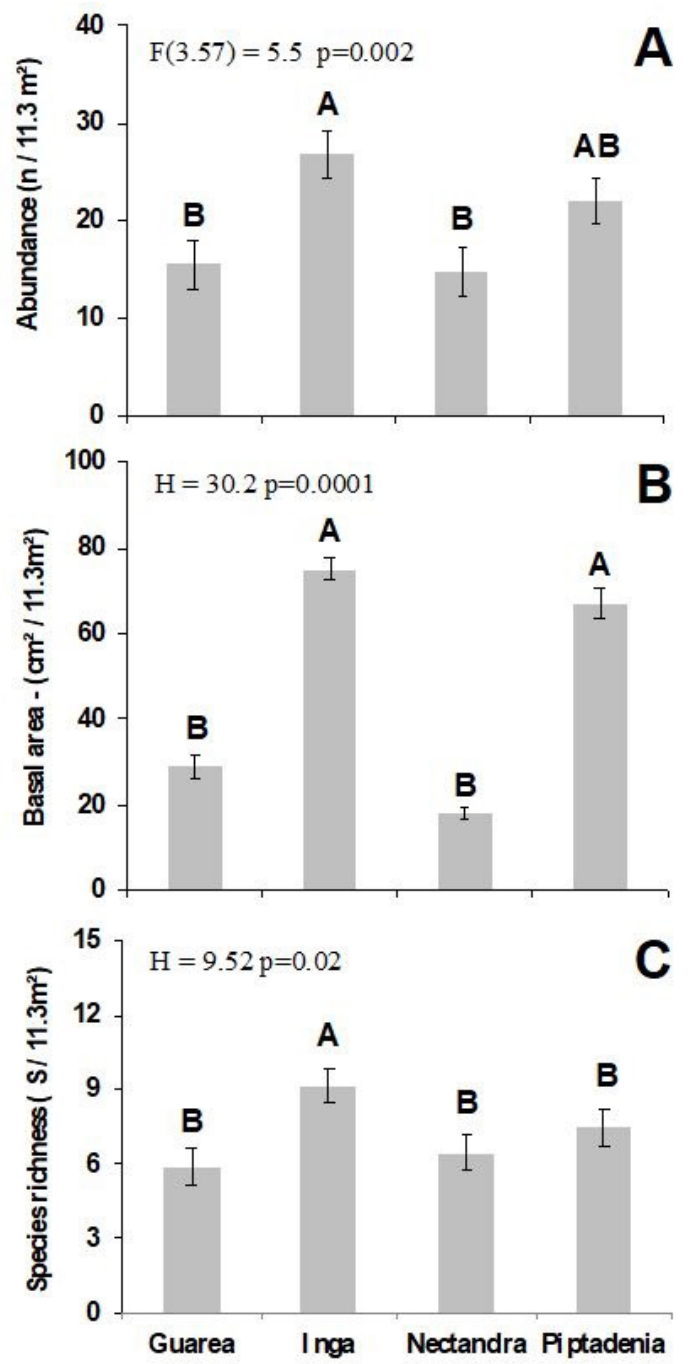

Figure 1. Changes in community structure (A, abundance; B, basal area) and species richness (C) of the naturally regenerated vegetation beneath four focal tree species in the Guapiaçu Ecological Reserve, Brazilian Atlantic Forest. Different letters above bars indicate significant differences at $\mathrm{p}<0.05$. species for Inga (Myrsine coriacea (Sw.) R.Br) and one species for Piptadenia (Moquiniastrum polymorphum (Cabrera) G. Sancho) (Table 2).

\section{DISCUSSION}

We found evidence that the identity of the tree species does affect natural regeneration beneath the canopy at sites under restoration in the Atlantic Forest. This supports the hypothesis we have proposed. Several studies have already described the effect of species composition in restoration projects on natural regeneration at the plot scale (Parrotta, 1995; Finegan \& Delgado, 2000; Carnevale \& Montagnini, 2002; Thijs et al., 2014). The studies cited above used similar mechanisms (e.g., dispersion syndrome, $\mathrm{N}$ fixation, and crown structure) to explain their results (Carnevale \& Montagnini, 2002; Thijs et al., 2014). However, our results demonstrated that this effect also occurs at the

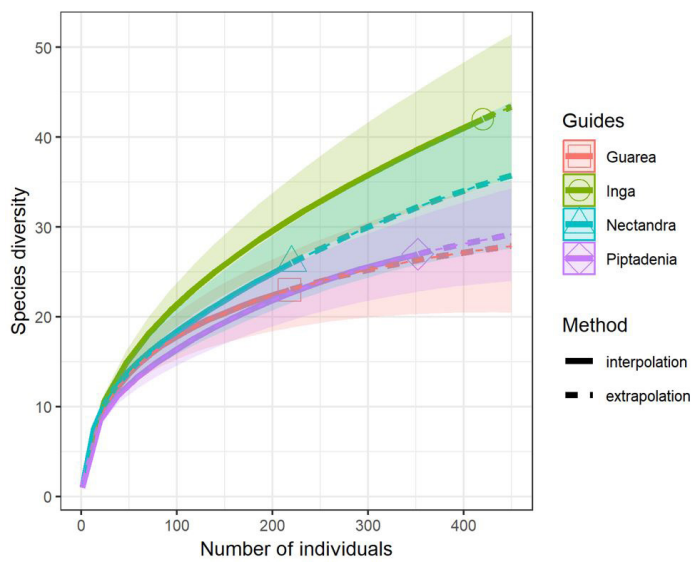

Figure 2. Number of species (rarefaction curves and confidence interval of 95\%) for the naturally regenerated vegetation beneath four focal tree species in the Guapiaçu Ecological Reserve, Brazilian Atlantic Forest.

Table 2. Indicator species analysis (ISA - IndVal) for natural regeneration beneath two tree species (Inga and Piptadenia) in the Guapiaçu Ecological Reserve, Brazilian Atlantic Forest.

\section{Tree species / Indicator species InVal p} Inga

Myrsine coriacea (Sw.) R.Br 0.4 0.004

\section{Piptadenia}

Moquiniastrum polymorphum

(Cabrera) G. Sancho)
0.3 0.05 
level of individual trees. Although this has already been demonstrated for tropical old-growth forests (Mejía-Domínguez et al., 2011; Souza et al., 2014), we believe that the novelty of our research is that it has indicated that these consequences may manifest even in the short term (10 years). In this way, the use of species that facilitate natural regeneration, such as Inga edulis, should be promoted in order to catalyze the ecological restoration process.

The positive effect of I. edulis on natural regeneration can be explained by the attributes of the species, such as the availability of its fruits to dispersers, and its biological nitrogen fixation (Canosa \& Moraes, 2016). Nitrogen fixation promotes soil fertility and, consequently, contributes to reducing barriers to the establishment and persistence of the seedling community. Inga species have been recommended in agroforestry systems due to their positive effects on soil conditions (Lojka et al., 2010). The second factor that should be considered is the attractiveness of the fruit to fauna (birds and mammals; Canosa \& Moraes, 2016). Communities with greater fruit availability for fauna may exhibit higher species richness in naturally regenerated vegetation (Sansevero et al., 2011). Research on restoration plantations has shown that the time spent by birds in I. edulis trees is higher than in other tree species (Fink et al., 2009). Thus, the permanent presence of birds in an area can increase seed rain and subsequently lead to an abundance of seedlings and saplings. In fact, the presence of the indicator species Myrsine coriacea (Primulaceae), which is also dispersed by birds (Canosa \& Moraes, 2016), may be associated with the interaction between Inga trees and fauna. Therefore, considering the larger role of I. edulis in accelerating natural regeneration and enhancing species richness relative to other species, it makes sense to use this species as a framework species (sensu Elliott et al., 2003). As such, its use in restoration projects must be promoted.

The results observed for Piptadenia may be associated with the lower environmental heterogeneity among trees of this species, compared with Inga, Nectandra and Guarea. Although it presented the second-highest value for average species richness, the rarefaction curve indicated the lowest values for species accumulation and beta diversity. Deciduous species present a greater availability of light under their canopies (Gandolfi et al., 2007). This may explain the presence of the pioneer species Moquiniastrum polymorphum (Asteraceae) as an indicator in the naturally regenerated vegetation. Since M. polymorphum exhibits anemochoric dispersion and produces a large number of seeds (Sansevero et al., 2017), limitation with respect to seed dispersal does not seem to be the main reason underlying the presence of this indicator species. The Nectandra and Guarea trees had the lowest average values for species richness, abundance, and basal area of the naturally regenerated vegetation. However, the curve for species accumulation under Nectandra trees was higher than those for Piptadenia and Guarea. This result may be associated with a greater environmental heterogeneity among trees of this species. However, a more precise analysis is needed to understand the mechanisms responsible for this outcome. In the case of G. guidonia, these results have large practical implications, since the species has been widely utilized in restoration projects in the Atlantic Forest (Sansevero et al., 2011; Azevedo, 2012; WebAmbiente, 2018).

\section{CONCLUSIONS}

Tree species planted matter to natural regeneration and, as a consequence, affect the maintenance of community structure and species richness in sites under restoration. Our results highlighted the role of Inga in increasing species richness, abundance and basal area of natural regeneration beneath their canopy. Availability of fruits to dispersers and ability to biological $\mathrm{N}$ fixation were suggested as the main inherent species traits to explain these effects on natural regeneration. Therefore, the use of Inga edulis in restoration program projects is highly recommended. Thus, we believe that this essay can offer a significant contribution to restorationists engaged in the ambitious restoration targets which have been committed. Finally, we also intend to emphasize the relevance of regarding tree species effects, positive (e.g. facilitation) or negative (e.g. inhibition), instead of simple response (mortality and initial growth), in drawing up a list of potential species to be utilized in ecological restoration initiatives.

\section{ACKNOWLEDGEMENTS}

The authors are very grateful to Nicholas Locke, Raquel Locke and Reserva Ecológica de Guapiaçu (REGUA) staff for logistical facilities and inspiration for biological 
conservation. We also thank CNPq and FAPERJ for granting scholarships (Programa de Iniciação Científica) to L.L Lameira, R.A.E Filardi, and F.C.G Ferreira.

\section{SUBMISSION STATUS}

Received: 23 oct., 2018

Accepted: 4 dec., 2018

\section{CORRESPONDENCE TO}

\section{Jerônimo Boelsums Barreto Sansevero}

Universidade Federal Rural do Rio de Janeiro

- UFRRJ, BR 456, Km 7, CEP 23890-000,

Seropédica, RJ, Brasil

e-mail: guapuruvu@gmail.com

\section{FINANCIAL SUPPORT}

CNPq and FAPERJ.

\section{REFERENCES}

APG IV. An update of the Angiosperm Phylogeny Group classification for the orders and families of flowering plants: APG IV. Botanical Journal of the Linnean Society 2016; 181(1): 1-20. http://dx.doi.org/10.1111/boj.12385.

Azevedo AD. Composição florística e estoque de carbono em áreas de recuperação da mata atlântica na bacia do Rio Guapiaçu, Cachoeiras de Macacu, RJ [Dissertação]. Seropédica: Universidade Federal Rural do Rio de Janeiro; 2012.

Cadotte MW, Carscadden K, Mirotchnick N. Beyond species: functional diversity and the maintenance of ecological processes and services. Journal of Applied Ecology 2011; 48(5): 1079-1087. http://dx.doi.org/10.1111/j.13652664.2011.02048.x.

Canosa GA, Moraes LFD. Atributos funcionais de espécies da Mata Atlântica: ferramentas para o planejamento ambiental e econômico [online]. Seropédica: Embrapa Agrobiologia; 2016 [cited 2016 out. 1]. (Documentos; no. 305). Available from: https://www.embrapa.br/busca-de-publicacoes/-/ publicacao/1056021/atributos-funcionais-de-especiesda-mata-atlantica-ferramentas-para-o-planejamentoambiental-e-economico

Carnevale NJ, Montagnini F. Facilitating regeneration of secondary forests with the use of mixed and pure plantations of indigenous tree species. Forest Ecology and Management 2002; 163(1-3):217-227. http://dx.doi. org/10.1016/S0378-1127(01)00581-3.
Clark CJ, Poulsen JR, Connor EF, Parker VT. Fruiting trees as dispersal foci in a semi-deciduous tropical forest. Oecologia 2004; 139(1): 66-75. http://dx.doi.org/10.1007/ s00442-003-1483-1. PMid:14745649.

Di Rienzo JA, Casanoves F, Balzarini MG, Gonzalez L, Tablada M, Robledo CW. InfoStat version 2015 [online]. Córdoba: Grupo InfoStat, Universidad Nacional de Córdoba. 2011 [cited 2016 out. 1]. Available from: http:// www. infostat.com.ar

Díaz S, Cabido M. Plant functional types and ecosystem function in relation to global change. Journal of Vegetation Science 1997; 8(4): 463-474. http://dx.doi.org/10.2307/3237198.

Dufrêne M, Legendre P. Species assemblages and indicator species: the need for flexible asymmetrical approach. Ecological Monographs 1997; 67(3): 345-366. http://dx.doi. org/10.2307/2963459.

Elliott S, Navakitbumrung P, Kuarak C, Zangkum S, Anusarnsunthorn V, Blakesley D. Selecting framework tree species for restoring seasonally dry tropical forests in northern Thailand based on field performance. Forest Ecology and Management 2003; 184(1-3): 177-191. http:// dx.doi.org/10.1016/S0378-1127(03)00211-1.

Finegan B, Delgado D. Structural and floristic heterogeneity in a 30 year-old costa rican rain forest restored on pasture through natural secondary succession. Journal of The Society for Ecological Restoration. 2000; 8(4): 380-393. http://dx.doi.org/10.1046/j.1526-100x.2000.80053.x.

Fink RD, Lindell CA, Morrison EB, Zahawi RA, Holl $\mathrm{KD}$. Patch size and tree species influence the number and duration of bird visits in forest restoration plots in Southern Costa Rica. Restoration Ecology 2009; 17(4): 479486. http://dx.doi.org/10.1111/j.1526-100X.2008.00383.x.

Gandolfi S, Joly CA, Rodrigues RR. Permeabilityimpermeability: canopy trees as biodiversity filters. Scientia Agrícola 2007; 64(4): 433-438. http://dx.doi.org/10.1590/ S0103-90162007000400015.

Garbin ML, Sánchez-Tapia A, Carrijo TT, Sansevero JBB, Scarano FR. Functional traits behind the association between climbers and subordinate woody species. Journal of Vegetation Science 2013; 25(3): 715-723. http://dx.doi. org/10.1111/jvs.12140.

Garbin ML, Zandavalli RB, Dillenburg LR. Soil patches of inorganic nitrogen in subtropical Brazilian plant communities with Araucaria angustifolia. Plant and Soil 2006; 286(1-2): 323-337. http://dx.doi.org/10.1007/ s11104-006-9046-y.

Grossnickle SC. Why seedlings survive: influence of plant attributes. New Forests 2012; 43(5-6): 711-738. http:// dx.doi.org/10.1007/s11056-012-9336-6.

Holl KD, Aide TM. When and where to actively restore ecosystems? Forest Ecology and Management 2011;261(10): 1558-1563. http://dx.doi.org/10.1016/j.foreco.2010.07.004. 
Isernhagen I, Moraes LFD, Engel VL. The rise of the Brazilian Network for Ecological Restoration (REBRE): what Brazilian restorationists have learned from networking. Restoration Ecology 2017; 25(2): 172-177. http://dx.doi. org/10.1111/rec.12480.

Lamb D, Erskine PD, Parrotta JA. Restoration of degraded tropical forest landscapes. Science 2005; 310(5754): 1628-1632. http://dx.doi.org/10.1126/science.1111773. PMid:16339437.

Laughlin DC. Applying trait-based models to achieve functional targets for theory-driven ecological restoration. Ecology Letters 2014; 17(7): 771-784. http://dx.doi. org/10.1111/ele.12288. PMid:24766299.

Lavorel S, Garnier E. Predicting changes in community composition and ecosystem functioning from plant traits: revisiting the Holy Grail. Functional Ecology 2002; 16(5): 545-556. http://dx.doi.org/10.1046/j.1365-2435.2002.00664.x.

Lindner A, Sattler D. Biomass estimations in forests of different disturbance history in the Atlantic Forest of Rio de Janeiro, Brazil. New Forests 2012; 43(3): 287-301. http://dx.doi.org/10.1007/s11056-011-9281-9.

Lojka B, Dumas L, Preininger D, Polesny Z, Banout J. The use and integration of Inga edulis in agroforesty systems in the Amazon: review article. Agricultura Tropica et Subtropica 2010; 43(4): 352-359.

McConkey KR, Prasad S, Corlett RT, Campos-Arceiz A, Brodie JF, Rogers H et al. Seed dispersal in changing landscapes. Biological Conservation 2012; 146(1): 1-13. http://dx.doi.org/10.1016/j.biocon.2011.09.018.

McGill BJ, Enquist BJ, Weiher E, Westoby M. Rebuilding community ecology from functional traits. Ecology and Evolution 2006; 21(4): 178-185. http://dx.doi.org/10.1016/j. tree.2006.02.002. PMid:16701083.

Mejía-Domínguez NR, Meave JA, Díaz-Ávalos C, González EJ. Individual canopy-tree species effects on their immediate understory microsite and sapling community dynamics. Biotropica 2011; 43(5): 572-581. http://dx.doi. org/10.1111/j.1744-7429.2010.00739.x.

Mendes MS, Latawiec AE, Sansevero JBB, Crouzeilles $\mathrm{R}$, Moraes LFD, Castro A et al. Look down-there is a gap-the need to include soil data in Atlantic Forest restoration. Restoration Ecology 2018; 27(2): 363-370.

Mesquita RCG, Ickes K, Ganade G, Williamson GB. Alternative successional pathways in the Amazon Basin. Journal of Ecology 2001; 89(4): 528-537. http://dx.doi. org/10.1046/j.1365-2745.2001.00583.x.

Ostertag R, Warman L, Cordel S, Vitousek PM. Using plant functional traits to restore Hawaiian rainforest. Journal of Apllied Ecology 2015; 52(4): 805-809. http:// dx.doi.org/10.1111/1365-2664.12413.

Parrotta JA. Influence of overstory composition on understory colonization by native species in plantations on a degraded tropical site. Journal of Vegetation Science 1995; 6(5): 627-636. http://dx.doi.org/10.2307/3236433.

Pistón N, Michalet R, Schob C, Macek P, Armas C, Pugnaire FI. The balance of canopy and soil effects determines intraspecific differences in foundation species' effects on associated plants. Functional Ecology 2018; 32(9): 2253-2263. http://dx.doi.org/10.1111/1365-2435.13139.

Rodrigues RR, Gandolfi S, Nave AG, Aronson J, Barreto TE, Vidal CY et al. Large scale ecological restoration of high diversity tropical forests in SE Brazil. Forest Ecology and Management 2011;261(10): 1605-1613. http://dx.doi. org/10.1016/j.foreco.2010.07.005.

Sansevero JBB, Garbin ML. Restoration success of tropical forests: the search for indicators. Sustainability Indicators 2015; Eds. Latawiec, AE \& Agol, D. De Gruyter Open Ltd. Warsaw - Poland.

Sansevero JBB, Prieto PV, de Moraes LFD, Rodrigues PJP. Natural regeneration in plantations of native trees in lowland brazilian atlantic forest: community structure, diversity, and dispersal syndromes. Restoration Ecology 2011; 19(3): 379-389. http://dx.doi.org/10.1111/j.1526100X.2009.00556.X.

Sansevero JBB, Prieto PV, Sánchez-Tapia A, Braga JMA, Rodrigues PJFP. Past land-use and ecological resilience in a lowland Brazilian Atlantic Forest: implications for passive restoration. New Forests 2017; 48(5): 573-586. http://dx.doi.org/10.1007/s11056-017-9586-4.

Scaramuzza CA, Benini RM, Biderman R, Brancalion PHS, Calmon M, Correa LQ et al. A política Nacional de Recuperação da Vegetação Nativa: lições aprendidas. In: Benini RM, Adeodato S. (Org.). Economia da restauração florestal. The Nature Conservancy; 2017. p. 5-135.

Scervino RP, Torezan MD. Factors affecting the genesis of vegetation patches in anthropogenic pastures in the Atlantic forest domain in Brazil. Plant Ecology \& Diversity 2015; 8(4): 475-482. http://dx.doi.org/10.1080/1755087 4.2015.1044582.

Siddique I, Engel VL, Parrotta JA, Lamb D, Nardoto GB, Ometto JPHB et al. Dominance of legume trees alters nutrient relations in mixed species forest restoration plantings within seven years. Biogeochemistry 2008; 88(1): 89-101. http://dx.doi.org/10.1007/s10533-008-9196-5.

Souza FM, Batista JLF. Restoration of seasonal semideciduous forests in Brazil: influence of age and restoration design on forest structure. Forest Ecology and Management 2004; 191(1): 185-200. http://dx.doi.org/10.1016/j. foreco.2003.12.006.

Souza FM, Gandolfi S, Rodrigues RR. Deciduousness INfIUENCES THE UNDERSTORY COMMUNITY IN A SEMIDECIDUOUS TROPICAL FOREST. Biotropica 2014; 46(5): 512-515. http://dx.doi.org/10.1111/btp.12137.

Suganuma MS, Assis GB, Durigan G. Changes in plant species composition and functional traits along the 
successional trajectory of a restored patch of Atlantic Forest. Community Ecology 2014; 15(1): 27-36. http:// dx.doi.org/10.1556/ComEc.15.2014.1.3.

Thijs KW, Aerts R, Van de Moortele P, Musila W, Gulinck $\mathrm{H}$, Muys B. Contrasting Cloud Forest Restoration Potential Between Plantations of Different Exotic Tree Species. Restoration Ecology 2014; 22(4): 472-479. http://dx.doi. org/10.1111/rec.12093.
Veloso HP, Filho ALRR, Lima JCA. Classificação da vegetação brasileira adaptada a um sistema universal [online]. Rio de Janeiro: IBGE; 1991 [cited 2016 out. 1]. Available from: http://hm-jbb.ibict.br/bitstream/1/397/1/1991_ classificacaovegetal_Velloso1991.pdf

WebAmbiente. Espécies nativas [online]. Embrapa; 2018 [cited 2016 out. 1]. Available from: https://www. webambiente.gov.br/publico/especies.xhtml 